\title{
SUSTAINABILITY OF CIRCULATION PATTERNS TO EASY MOBILITY VISITORS \\ CASE STUDY: PALACE BANDUNG ELECTRONIC CENTER, BANDUNG
}

\author{
${ }^{1}$ Deviani Susanto. ${ }^{2}$ Ir. Alexander Sastrawan, MSP \\ ${ }^{1}$ Student in the Bachelor's (S-1) Study Program in Architecture \\ at Parahyangan Catholic University \\ 2 Senior lecturer in the Bachelor's (S-1) Study Program in Architecture \\ at Parahyangan Catholic University
}

\begin{abstract}
The addition of new buildings especially in the shopping center building is often the case, it aims to develop activities in old shopping buildings that are considered to have potential in maintaining or improving the quality of a shopping center, but the development can be a problem if in the initial development of a shopping center has no plans for adding or thinking about the second stage of development for some time to come. As a result, the designer must be able to create a connection circulation path in the building design that looks united between the old building and the new building into a unified whole, but there are several factors that must be adapted to the condition and state of the old building so that the resulting building can be continuous with each other.

This research will discuss about the circulation inside the shopping center building, especially on the continuity between circulation pattern of old building and new building of shopping building. The object used is electronic shopping center Istana Bandung Electronic Center or often called BEC located at Jalan Purnawarman no 13-15, Bandung.

Qualitative method is done by collecting data from object of study in the form of plan, documentation of picture or photo, study of literature, theories, and so on. Quantitative methods are carried out by listing the mobility of visitors within the building, especially in the path of meeting the circulation patterns between old and new buildings in the BEC shopping area.

The purpose of this research is to know the continuity of circulation pattern between old building and new building as one shopping center, seen from the ease of visitor mobility inside the building, and to know and to evaluate the effectiveness of combined circulation pattern between old building and new building inside shopping area Istana Bandung Electronic Center.
\end{abstract}

Key Words: continuity, circulation patterns, ease of visitor mobility, shopping center.

\section{KESINAMBUNGAN POLA SIRKULASI TERHADAP KEMUDAHAN MOBILITAS PENGUNJUNG STUDI KASUS: ISTANA BANDUNG ELECTRONIC CENTER, BANDUNG}

\author{
${ }^{1}$ Deviani Susanto. ${ }^{2}$ Ir. Alexander Sastrawan, MSP \\ ${ }^{1}$ Mahasiswi S1 Program Studi Arsitektur Universitas Katolik Parahyangan. \\ 2 Dosen Pembimbing S1 Program Studi Arsitektur Universitas Katolik Parahyangan.
}

\begin{abstract}
Abstrak- Penambahan bangunan baru khususnya pada bangunan pusat perbelanjaan seringkali terjadi, hal ini bertujuan untuk mengembangkan aktivitas di gedung perbelanjaan lama yang dianggap berpotensi dalam menjaga ataupun meningkatkan kualitas suatu pusat perbelanjaan, namun pengembangan tersebut dapat menjadi masalah jika dalam pembangunan awal suatu pusat perbelanjaan tidak memiliki rencana untuk menambah atau memikirkan
\end{abstract}

${ }^{1}$ Corresponding Author: devianisusanto@gmail.com 
tahap pembangunan kedua pada beberapa waktu kedepannya. Dampaknya, perancang harus mampu membuat jalur pertemuan sirkulasi di dalam rancangan bangunan yang terlihat menyatu antara gedung lama dan gedung baru menjadi satu kesatuan utuh, namun ada beberapa faktor yang harus disesuaikan dengan kondisi dan keadaan bangunan gedung lama agar bangunan yang dihasilkan dapat sinambung satu sama lain.

Penelitian ini akan membahas mengenai sirkulasi di dalam bangunan pusat perbelanjaan, khususnya pada kesinambungan antara pola sirkulasi bangunan lama dan bangunan baru gedung perbelanjaan. Objek yang digunakan adalah pusat perbelanjaan elektronik Istana Bandung Electronic Center yang terletak di Jalan Purnawarman no $13-15$, Bandung.

Penelitian dilakukan dengan menggunakan metode kualitatif dan kuantitatif dengan mengumpulkan data-data dari objek studi berupa denah, dokumentasi gambar atau foto dan studi literatur serta mendata mobilitas pengunjung di dalam bangunan khususnya pada jalur pertemuan pola sirkulasi antar bangunan gedung lama dan baru yang ada di dalam area perbelanjaan BEC.

Tujuan dari penelitian ini untuk mengetahui kesinambungan pola sirkulasi antar gedung lama dan gedung baru sebagai satu kesatuan pusat perbelanjaan, dilihat dari kemudahan mobilitas pengunjung di dalam bangunan, serta mengetahui dan menilai efektivitas gabungan pola sirkulasi antar gedung lama dan gedung baru di dalam area perbelanjaan Istana Bandung Electronic Center.

Kata Kunci: kesinambungan, pola sirkulasi, kemudahan mobilitas pengunjung, pusat perbelanjaan.

\section{PENDAHULUAN}

Pada saat ini, penambahan bangunan baru khususnya pada bangunan pusat perbelanjaan seringkali terjadi di kota-kota besar yang memiliki perkembangan yang pesat. Penambahan bangunan berupa pembuatan gedung baru bertujuan untuk mengembangkan aktivitas di gedung perbelanjaan lama, yang dianggap dengan perluasan ini dapat berpotensi dalam menjaga ataupun meningkatkan kualitas suatu pusat perbelanjaan.

Pembuatan gedung baru untuk mengembangkan aktivitas pada gedung perbelanjaan lama dapat menjadi masalah jika, dalam pembangunan awal suatu pusat perbelanjaan tidak memiliki rencana untuk menambah atau memikirkan tahap pembangunan kedua pada beberapa waktu kedepannya. Dampaknya, perancang harus mampu membuat jalur pertemuan di dalam rancangan bangunan yang terlihat menyatu antara gedung lama dan gedung baru menjadi satu kesatuan utuh, namun ada beberapa faktor utama pada bangunan perbelanjaan yang harus disesuaikan. Menurut Nadine Beddington faktor utama dalam bangunan pusat perbelanjaan adalah konsep utama, layout, dan sirkulasi. Penyesuaian faktor tersebut di dalam rancangan gedung perbelanjaan baru dapat dikatakan berhasil bila mampu menyatu dan melebur menyesuaikan dengan kondisi pada gedung yang sudah ada sebelumnya, prinsip utama keberhasilan rancangan dapat ditemukan dari sirkulasi pengguna khususnya pengunjung yang baru pertama kali datang dapat berjalan secara lancar dan mengalir dari awal hingga akhir perjalanan.

Efektivitas menjadi poin penting untuk membantu memudahakan pengguna, efektivitas dapat dilihat dari sirkulasi pengguna, khususnya pada pusat perbelanjaan adalah sirkulasi pengunjungnya. Dalam hal sirkulasi pengunjung, faktor yang harus dipertimbangkan berkaitan erat dengan kesinambungan antar bangunan lama dan bangunan baru dilihat dari pergerakan pengunjung di dalamnya. Sirkulasi pengunjung kemudian difokuskan pada pengguna jalur pedestrian, drop off, dan area penerima utama. Sirkulasi yang dirancang diharapkan dapat mempermudah pengguna dari luar hingga masuk berkeliling di dalam bangunan gedung, sikulasi kemudian dapat dibagi menjadi sirkulasi eksternal dan sirkulasi internal. Sirkulasi secara eksternal dapat berupa akses pencapaian pada tapak menuju pintu masuk utama bangunan, dengan syarat akses pada bangunan komersil harus dapat mudah dicapai guna mempermudah sirkulasi pengunjung. Secara internal, sirkulasi di dalam bangunan harus dapat dilalui secara merata oleh pengunjung, diharapkan tidak terdapat area mati pada area tertentu di dalam bangunan. 
Pembahasan mengenai sirkulasi dapat berkaitan erat dengan pergerakan dan flow activity atau secara singkat dikatan sebagai mobilitas pengunjung baik itu secara horizontal, vertikal, dan diagonal. Sirkulasi pada bangunan perbelanjaan kemudian dapat dikaitkan dengan penataan fisik berupa penataan jenis layout bangunan perbelanjaan dan zoning kegiatan, daripenataan fisik yang ada maka dapat ditemukan suatu pola sirkulasi.

Melalui latar belakang tersebut, maka dalam penelitian ini akan dibahas mengenai sirkulasi di dalam bangunan pusat perbelanjaan, khususnya pada kesinambungan pola sirkulasi antara bangunan lama dan bangunan baru gedung perbelanjaan. Efektivitas sirkulasi pada bangunan perbelanjaan kemudian secara lebih jauh dapat ditinjau dari penataan layout, media sirkulasi, zoning, dan penempatan tenant yang kemudian akan mempengaruhi kemudahan mobilitas pengunjung khususnya di jalur pertemuan pola sirkulasi antar bangunan gedung lama dan gedung baru. Objek yang digunakan untuk menggambarkan fenomena permasalahan yang telah disampaikan di atas adalah pusat perbelanjaan Istana Bandung Electronic Center atau sering disebut BEC yang terletak di Jalan Purnawarman no 13 - 15, Bandung.

Penelitian ini bertujuan untuk mengetahui kesinambungan pola sirkulasi di dalam bangunan Istana Bandung Electronic Center (BEC), sebagai pusat perbelanjaan yang dibangun secara bertahap, serta menilai efektivitas jalur sirkulasi pengunjung yang ada di dalam bangunan Istana Bandung Electronic Center khususnya dalam memudahkan pengunjung dalam melakukan mobilitas, mobilitas dicapai dari titik masuk hingga tujuan yang ditempuh didasarkan pada kebutuhan dan media sirkulasi yang ada.

Metode yang digunakan dalam penelitian ini adalah metode kualitatif dan kuantitatif, berupa: (1) mengumpulkan data-data dari objek studi berupa tenant, media sirkulasi, denah, dokumentasi gambar/ foto, studi literatur, teori-teori, dan sebagainya (2) survey langsung ke dalam lapangan guna mendapatkan data penghitungan jumlah pengunjung yang melakukan pergerakan tepat pada jalur pertemuan pola sirkulasi lantai Lower Upper - Lantai 3, dilakukan pada jam terpadat dalam 1 pekan yaitu hari sabtu tanggal 1 \& 8 April 2017 (pukul 16.00 17.00) dan hari minggu tanggal $2 \& 9$ April 2017 (pukul 15.00 - 16.00).

\section{POLA SIRKULASI ISTANA BANDUNG ELECTRONIC CENTER}

\subsection{TIPOLOGI}

Bandung Electronic Center awalnya sebelum terdapat BEC2 berdasarkan tipologi pusat perbelanjaan yang diungkapkan oleh ICSC's Asia Research Council lebih mengarah pada tipe Niche/ destination retail dengan ciri utama kategori penjualan barang khusus dan retail-retail tanpa anchor utama, dalam hal ini BEC 1 mengarah pada penjualan elektronik khususnya handphone, komputer, dan kamera, dengan persentase terbesar tenant handphone sebesar $45 \%$, dan computer $23 \%$. Setelah terdapat BEC2 dan penambahan fungsi-fungsi baru, tipe pusat perbelanjaan ini menjadi lebih mengarah pada tipe Super Regional karena memiliki anchor baru dan fungsi yang berbeda dari konsep elektronik, anchor yang ada berupa supermarket yaitu Lotte Mart pada lantai USL, Electronic Solution yang merupakan department store di lantai 3, café, restaurant dan food court yang tersebar pada tiap lantai, dan entertainment berupa Game Mater di lantai 3, bioskop Blitz Megaplex pada lantai L3A, terlihat dari diagram yang ada tenant entertainment merupakan tenant tertinggi pada gedung yang baru sebesar $21 \%$ (Figur 1.) Berdasarkan persentase tipe penjualan di dalamnya maka didapatkan data sebagai berikut. 

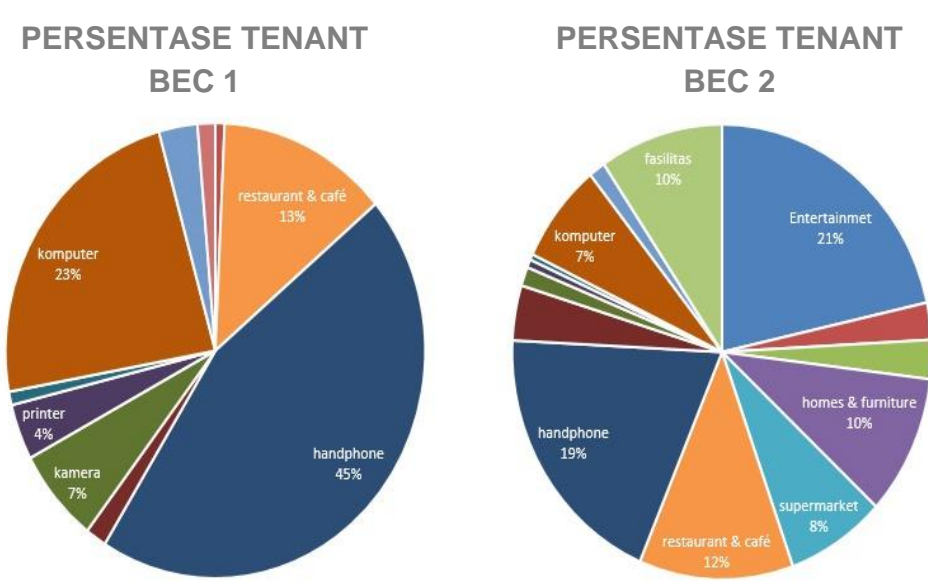

Figur 1. Diagram PersentaseTenant di BEC 1 \& BEC 2

\subsection{PENCAPAIAN KE DALAM BANGUNAN}

Secara umum dilihat dari entrance dalam tapak BEC, kecenderungan orang memilih entrance yang terlehat lebih dahulu secara visual. Hal ini terjadi pada kasus entrance di BEC, dalam pemilihannya pengunjung cenderung memilih masuk pada titik 1 (Figur 2) hal ini dikarenakan Jalan Punawarman hanya menyediakan jalur sirkulasi transportasi searah dimulai dari arah utara BEC. Secara kepadatannya pengunjung titik 1 memiliki kepadatan 55\%, titik 2 sekitar 35\%, dan titik 3 sekitar 10\%. Dilihat dari arah visual pencapaiannya dari jalan, entrance 1 dan 2 memiliki pencapaian yang tersamar dimana orang harus mencari dulu entrance dari sudut pandang mereka, dan untuk entrance 3 pengunjung tidak akan mengetahui bila sudah melewati sisi bangunan bagian timur dan berbelok arah.

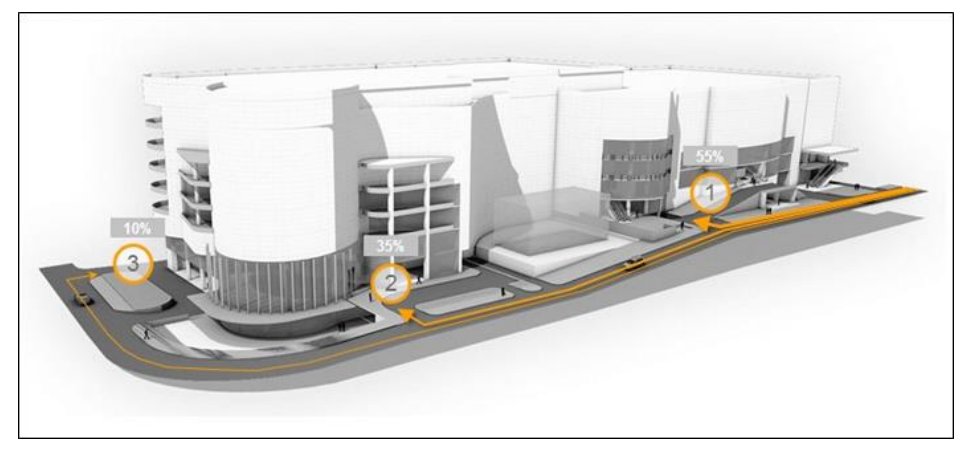

Figur 2. Kecenderungan Pemilihan Entrance oleh Pengunjung

Lebih jauh masuk ke dalam bangunan, penggunaan entrance (Figur 3.) sebenarnya memberikan arah tujuan ke level lantai yang berbeda-beda, hal ini menyesuaikan dengan ketinggian tapak di dalam bangunan. Pada entrance 1 diarahkan pada lantai LU, LG, dan UG , entrance 2 di lantai USL, dan entrance 3 di lantai SL. Penggunaan entrance pengunjung lebih dari satu dalam 1 bangunan dapat dikatakan bangunan ini memiliki konsep multientrance, biasa penggunaan multientrance ini dikarena bangunan memiliki sisi yang menghadap pada jalan yang berbeda. 


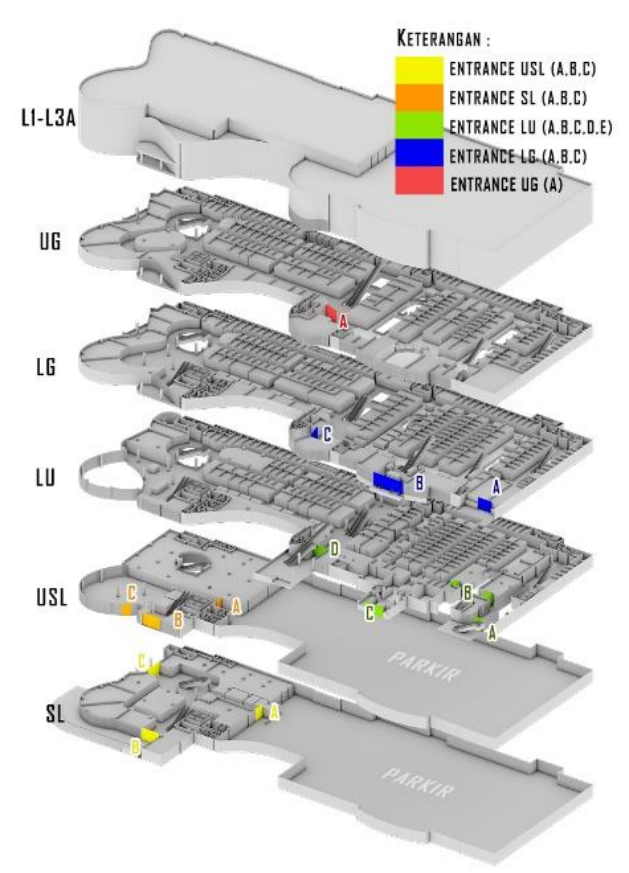

Figur 1. .Entrance ke dalam Bangunan

\subsection{KATEGORI LAYOUT}

Secara keseluruhan Bandung Electronic Center merupakan pusat perbelanjaan yang bersifat tertutup/ enclosed shopping centre, dan merupakan bangunan yang di redeveloped.

Bangunan BEC pada tahun 2002 memiliki layout pusat perbelanjaan Loop / Racetrack Plan dimana pengunjung berjalan secara berputar untuk menuju ke lantai yang lain. Namun setelah penambahan BEC2 yang dibuka pada tahun 2014, layout bangunan gedung lama masih melekat dan tampak utuh tanpa perubahan baik dari sisi tenant koridor, eskalator, dan penempatan entrance utama, perbedaan muncul dengan penghilangan bagian tertentu untuk dijadikan sebagai jalur-jalur pertemuan yang mempertemukan antara gedung lama dan gedung baru.

Dilihat secara terpisah dari gedung yang lama, gedung baru memiliki sirkulasi yang cenderung linear (Figur 4.), dilihat dari denah, penggabungan layout tersebut hanya disambungkan dengan titik-titik berupa jalur pertemuan antara layout gedung lama dan layout gedung baru (layout loop dan linear).

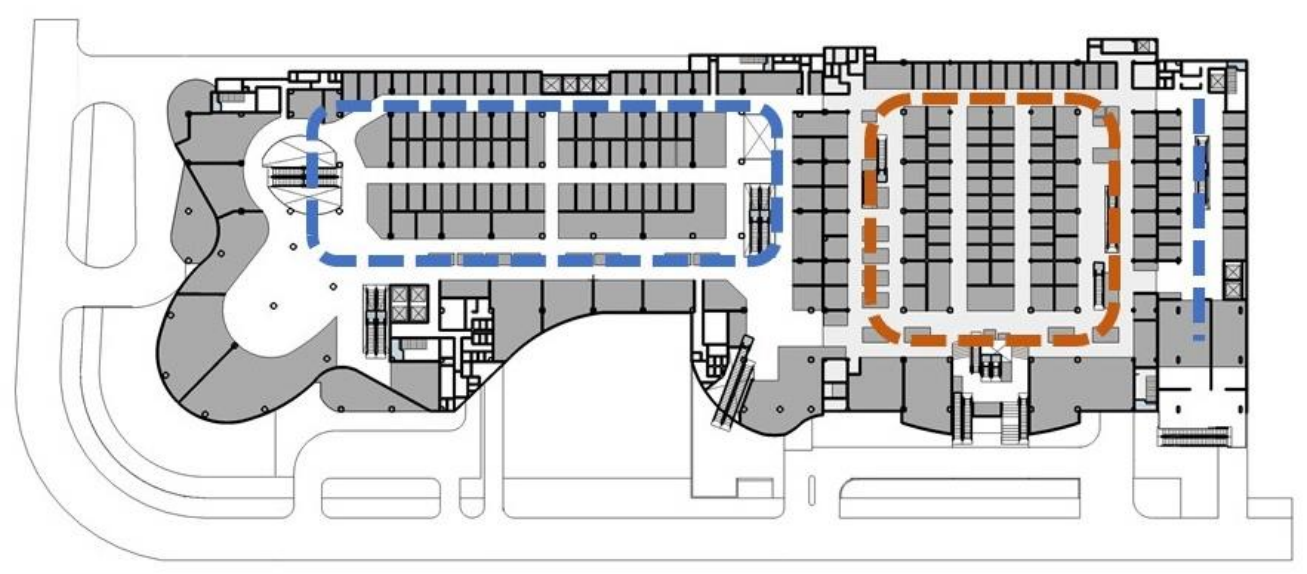

Figur 4. Layout Denah linear di BEC baru dan loop di BEC lama Lantai LG 


\subsection{KORIDOR DAN NODE}

Dilihat dari perbedaan layout sirkulasi yang terletak pada gedung lama dan gedung baru BEC, secara lebih jauh akan dianalisa peletakan koridor dan node untuk mendapatkan pola sirkulasi yang terbentuk. Penggunaan node dipakai untuk mempermudah pengunjung dalam mengenali suatu lokasi, karena node memiliki suatu identitas dan menjadi titik kumpul beberapa koridor.

Dilihat dari gambar skema koridor di lantai LU sampai lantai L2, hubungan node antara bangunan lama dan bangunan baru di sisi utara dianggap memiliki potensi (Figur 5) karena adanya titik-titik node yang saling berhubungan, masalah yang muncul adalah node pada bangunan baru di sisi utara tak dapat dilihat dengan mudah dari entrance, dikarenakan pada sisi terdekat entrance tak dimunculkan jalur hierarki terkuat. Hal ini mengakibatkan bangunan baru pada sisi utara tak mendapat akses jalur utama secara mudah dari entrance drop off bangunan utama.

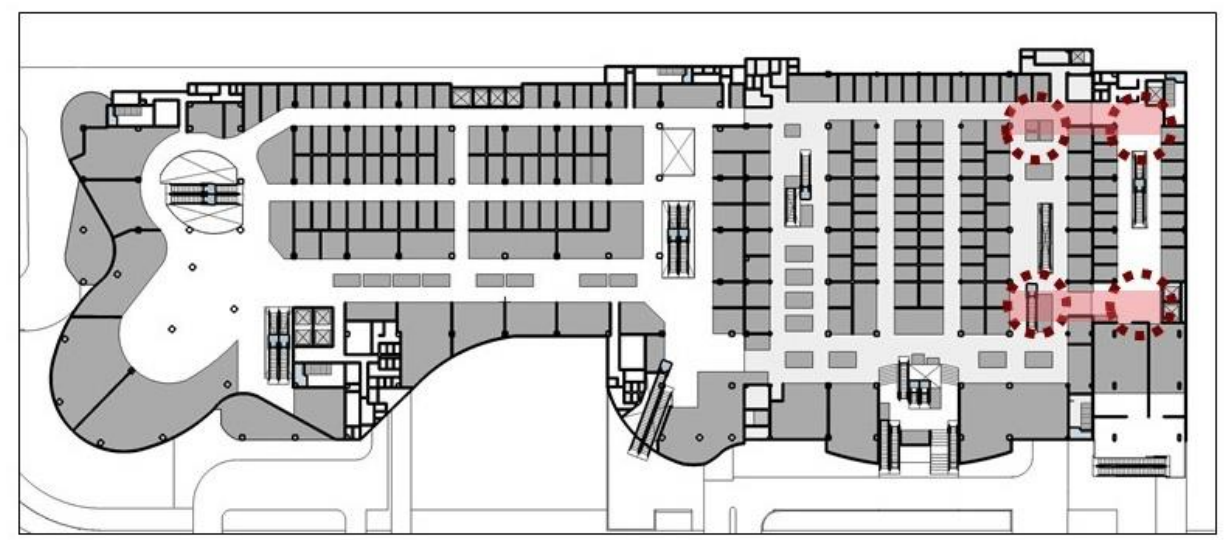

Figur 5. Hubungan Sirkulasi Utama BEC Baru Utara dan BEC Lama

Setelah melihat perbandingan denah dari bangunan lama sebelum terdapat bangunan baru (tahun 2002) dan sesudah ada penambahan bangunan baru (tahun 2017), pola sirkulasi yang dipengaruhi entrance, koridor, dan node secara keseluruhan masih dipertahankan oleh bangunan lama dan tidak dilakukan perubahan. Pada tabel 1. Dijelaskan dan ditemukan perbandingan bahwa bangunan BEC baru secara tipe dan layout memiliki sesuatu yang baru yang dari tipe dan layout di BEC lama.

Tabel 1. Tabel Hasil Kesinambungan Pola Sirkulasi BEC

\begin{tabular}{|c|c|c|c|}
\hline \multirow{3}{*}{$\begin{array}{c}\text { Massa } \\
\text { Bangunan }\end{array}$} & \multicolumn{3}{|c|}{ Pembentukan Pola Sirkulasi } \\
\hline & Entrance & Layout \& Tipe & Koridor \& Node \\
\hline & \multicolumn{3}{|c|}{ Terhadap Kesinambungan Pusat Perbelanjaan } \\
\hline $\begin{array}{l}\text { BEC } \\
\text { Lama }\end{array}$ & $\begin{array}{l}\text { Pengunjung yang kurang } \\
\text { familiar dengan kondisi di } \\
\text { dalam BEC lebih memilih } \\
\text { entrance di BEC lama, hal } \\
\text { ini dipengaruhi dari } \\
\text { pemikiran entrance hanya } \\
\text { ada pada awal pencapaian } \\
\text { tapak. }\end{array}$ & 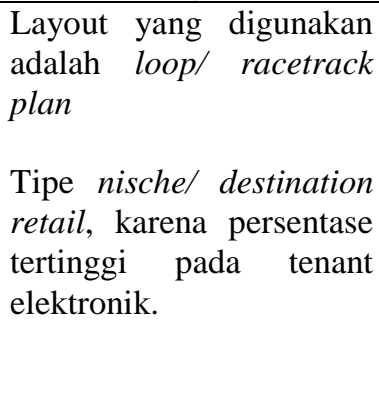 & $\begin{array}{l}\text { Node terkuat berada pada } \\
\text { dekat entrance dan } \\
\text { pertemuan sirkulasi di } \\
\text { ujung bangunan lama } \\
\text { sebagai titik putar atau } \\
\text { titik belok pengunjung ke } \\
\text { koridor lain, namun } \\
\text { hierarki koridor hanya } \\
\text { terlihat jelas pada } \\
\text { beberapa lantai. }\end{array}$ \\
\hline
\end{tabular}




\begin{tabular}{|c|c|c|c|}
\hline \multirow{3}{*}{$\begin{array}{c}\text { Massa } \\
\text { Bangunan }\end{array}$} & \multicolumn{3}{|c|}{ Pembentukan Pola Sirkulasi } \\
\hline & Entrance & Layout \& Tipe & Koridor \& Node \\
\hline & \multicolumn{3}{|c|}{ Terhadap Kesinambungan Pusat Perbelanjaan } \\
\hline $\begin{array}{l}\text { BEC } \\
\text { Baru }\end{array}$ & $\begin{array}{l}\text { Pengunjung yang familiar } \\
\text { dengan kondisi di dalam } \\
\text { BEC memilih kemudahan } \\
\text { dengan memilik entrance } \\
\text { lain di sisi selatan, hal ini } \\
\text { untuk mencapai tempat } \\
\text { yang ingin dituju secara } \\
\text { cepat, misal food district } \\
\text { atau lotte mart. }\end{array}$ & $\begin{array}{l}\text { Layout yang digunakan } \\
\text { adalah linear plan. } \\
\text { Tipe super regional } \\
\text { karena persentase } \\
\text { tertinggi pada fungsi } \\
\text { supermarket, department } \\
\text { store, cafél restaurant, } \\
\text { dan entertainment. }\end{array}$ & $\begin{array}{l}\text { Node terasa pada } \\
\text { pertemuan sirkulasi di } \\
\text { ujung gedung baru, } \\
\text { namun node yang ada } \\
\text { tidak semua dapat } \\
\text { terhubung dengan jalur } \\
\text { sirkulasi koridor utama.. }\end{array}$ \\
\hline $\begin{array}{l}\text { Pengga- } \\
\text { bungan }\end{array}$ & $\begin{array}{l}\text { Penggunaan } \\
\text { multientrance dianggap } \\
\text { kurang efektif diterapkan } \\
\text { pada bangunan yang } \\
\text { memiliki arah hadap jalan } \\
\text { jalur satu arah. }\end{array}$ & $\begin{array}{l}\text { Layout dan tipe penjualan } \\
\text { yang berbeda pada massa } \\
\text { bangunan lama dan baru. }\end{array}$ & $\begin{array}{l}\text { Node dan koridor antar } \\
\text { gedung baru dan lama tak } \\
\text { diarahkan dengan mudah } \\
\text { secara visual. }\end{array}$ \\
\hline
\end{tabular}

Maka hasil yang muncul dari hasil tabel perbandingan diatas, BEC dalam tatanan pola sirkulasi dalamnya memiliki 2 pola sirkulasi yang berbeda antara bangunan gedung lama dan gedung baru. Namun untuk kesinambungan pola sirkulasi BEC dianggap sinambung karena mobilitas pengunjung di dalam bangunan tetap berjalan.

\section{JALUR PERTEMUAN POLA SIRKULASI}

Sirkulasi pengunjung secara internal di dalam BEC ditampilkan secara berbeda di tiap lantainya, maka akan dibahas pada bab berikutnya mengenai kondisi jalur pertemuan yang mengarahkan pergerakan pengunjung antara pola sirkulasi gedung lama (loop) dan gedung baru (linear) pada batas di sisi utara dan gedung baru di sisi selatan, dikaitkan dengan variabel dimensi, visual pengunjung, media sirkulasi, dan tenant tujuan. Jalur pertemuan 2 pola sirkulasi ini hanya terbentuk di LU, LG, UG, L1, L2, dan L3 saja. Maka akan dianalisa jalur pertemuan pada 6 lantai terkait.

\subsection{LOWER UPPER}
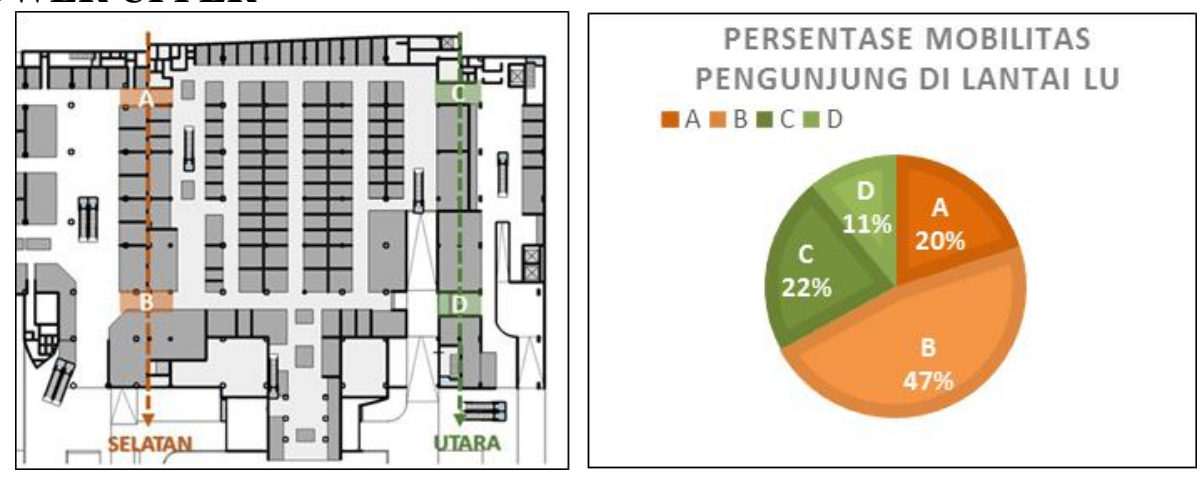

Figur 6. Posisi Jalur Pertemuan Pola (kiri) dan Persentase Jumlah Pengguna (kanan) di lantai LU

Dilihat dari diagram persentase mobilitas pengunjung di lantai LU, pada bagian jalur B, memiliki persentase tertinggi $47 \%$ dari Lantai LU, faktor yang bisa dilihat dari sisi visual, jalur B selatan adalah jalur yang terdekat dengan entrance, sejalur juga dengan entrance lain di Lantai Utama khususnya di gedung lama, memiliki dimensi lebar 3 meter dan dianggap 
mencukupi bila dilihat dari dimensi standart minimal 3 meter untuk jalur sirkulasi bersih pengunjung suatu pusat perbelanjaan.

Persentase terendah didapat pada jalur D, hal ini disebabkan adanya cross circulation antara pengunjung dengan kendaraaan, jalur pertemuan ini dipisahkan dengan entrance parkir basement, sehingga untuk keselamatan pengunjung guna menuju ke tempat fasilitas di bagian utara lebih memilih menggunakan jalur C.

\subsection{LOWER GROUND}
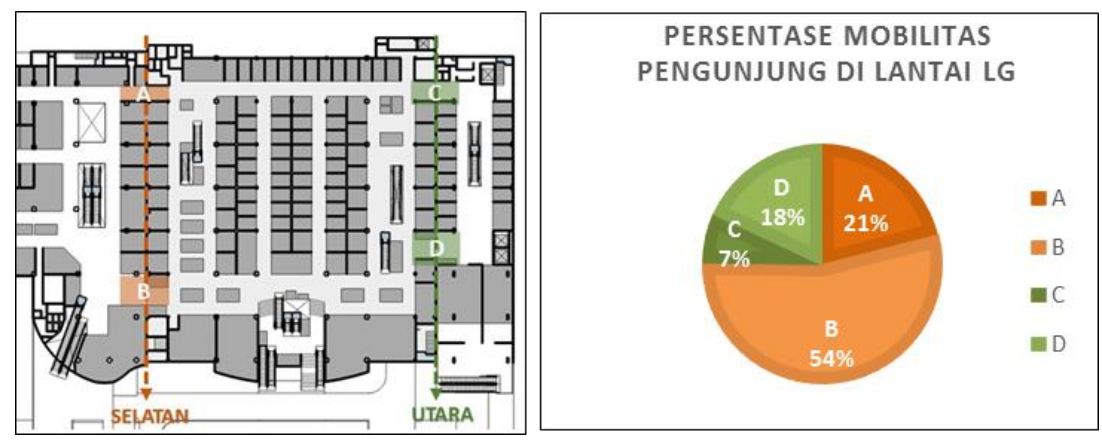

Figur 7. Posisi Jalur Pertemuan Pola (kiri) dan

Persentase Jumlah Pengguna (kanan) di lantai LG

Dilihat dari diagram persentase mobilitas pengunjung di lantai LG dan lalu lalang secara keseluruhan jalur pertemuan pola, Jalur B sebesar 54\%, beberapa hal pendukung dapat dilihat dari entrance utama bangunan, serta adanya koridor dengan hierarki yang melewati jalur ini. Secara sisi visual jalur B paling terlihat lebar karena dinding koridor dibuat sejajar dengan unit tenant yang ada di gedung lama, serta kesan lapang karena tak semua bagian jalur ditutup dengan dinding. Lebar koridor sesungguhnya di jalur ini memiliki lebar 7,2 meter, namun lebar bersih setelah dipakai tenant menjadi 3,4 meter. Namun kesan visual yang luas memberikan ketertarikan pengunjung untuk berlalu lalang.

Dilihat dari jalur pertemuan sisi utara secara keseluruhan, tepatnya pada jalur D di lantai ini memiliki mobilitas tertinggi untuk lalu lalang pengunjung ke gedung baru bagian utara, beberapa hal dapat dilihat bahwa memang jalur ini berada paling dekat dengan entrance utama khususnya entrance titik B (Figur 3), hal lain karena kebutuhan pengunjung menggunakan media sirkulasi yang dianggap cepat yaitu lift dan jalur yang dibuka tepat berada di depan lobby lift membuat pengunjung lebih mudah mengenali dan tertarik. Hal penunjang lain karena adanya fasilitas atm BCA yang ada tepat di sisi tersebut, sehingga pengunjung secara terpaksa harus menuju ke area tersebut untuk melakukan transaksi.

\subsection{UPPER GROUND}

Dilihat dari persentase mobilitas pengunjung di lantai LG, jalur yang banyak digunakan berada pada jalur B, hal pendukung yang sangat jelas terlihat adalah terbukanya jalur dan dimensi yang disejajarkan dengan jalur utama gedung lama, dimensi pada jalur ini mencapai 7,2 meter, sehingga bila dilihat memang kondisi gedung lama dapat dengan mudah dilihat dari gedung baru, dan sebaliknya. Hal lain jalur ini dilewati oleh jalur yang memiliki hierarki tertinggi antara pada bangunan lama dan bangunan baru, seperti pada pembahasan sebelumnya (Figur 6). Jalur A memiliki dimensi lebar sirkulasi 2,8 meter yang tidak memenuhi standart, sebesar minimal 3 meter namun penggunaan jalur ini $2 x$ lebih banyak dilalui bila dibandingkan dengan jalur $\mathrm{C}$ dan $\mathrm{D}$ yang memenuhi strandart. 


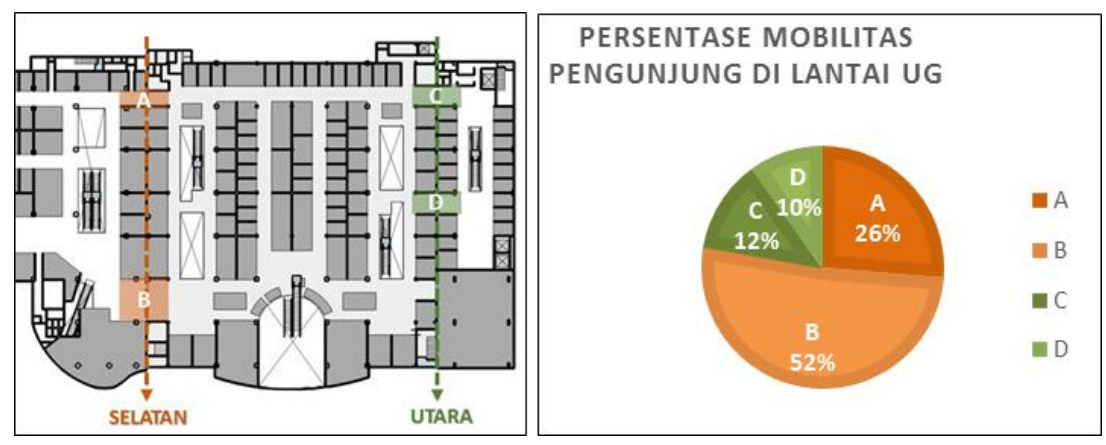

Figur 8. Posisi Jalur Pertemuan Pola (kiri) dan

Persentase Jumlah Pengguna (kanan) di lantai UG

\subsection{LANTAI 1}
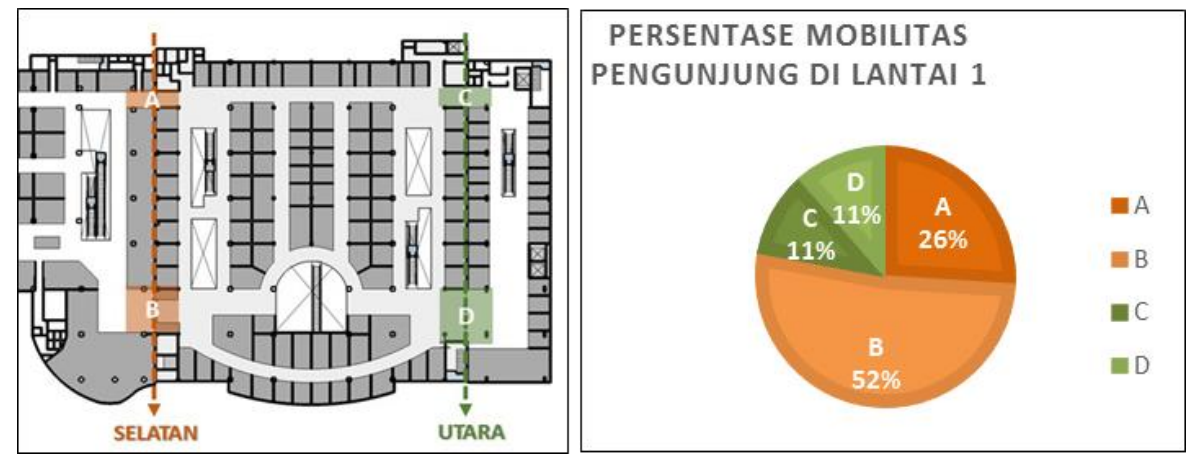

Figur 2. Posisi Jalur Pertemuan Pola (kiri) dan Persentase Jumlah Pengguna (kanan) di lantai 1.

Lantai 1 untuk persentase mobilitas terbesar pada jalur pertemuan B, dengan lebar koridor 7,2 meter, namun karna adanya inline tenant, lebar bersih jalur ini hanya 4 meter, hal ini juga dilakukan penerapan yang sama dengan jalur B yang ada di Lower Ground, meskipun dimensi bersih untuk sirkulasi pengunjung cukup kecil namun punya visual yang lebar, didukung juga keberadaan inline tenant yang turut mengundang ketertarikan pengunjung. Jalur sirkulasi A memiliki dimensi jalur terkecil sebesar 2,8 meter, hal ini tidak memenuhi standart minimal lebar sirkulasi dan penggunaanya $2 \mathrm{x}$ lebih banyak dilewati daripada jalur $\mathrm{C}$ dan $\mathrm{D}$.

\subsection{Lantai 2}
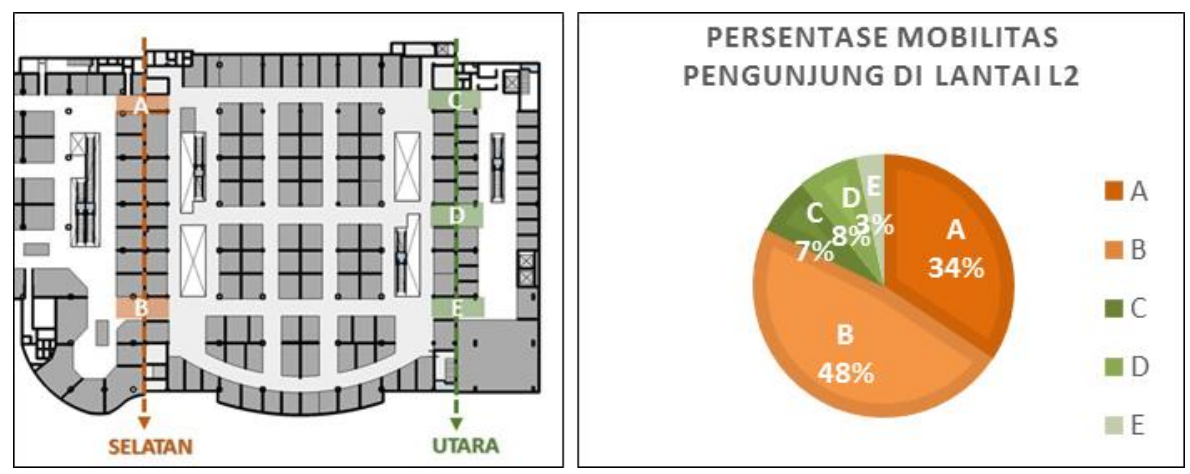

Figur 10.Posisi Jalur Pertemuan Pola (kiri) dan Persentase Jumlah Pengguna (kanan) di lantai L2. 
Jalur pertemuan di lantai ini, pada sisi utara dianggap cukup berbeda penyelesaiannya dengan jalur pertemuan di level lantai sebelumnya, hal ini dikarenakan terdapat 3 jalur yang tiap jalurnya memiliki dimensi yang dibuat sama rata dengan dengan koridor yang ada di BEC 1, jalur D dibuat sejajar dengan akses menuju atau ke eskalator, sehingga aksesnya dianggap paling banyak dilalui dari ketiga jalur yang telah dibuat, untuk sisi selatan jalur B paling banyak dilewai oleh pengunjung sebesar $48 \%$, lebar bersih sirkulasinya sebesar 3,7m dan dianggap merupakan jalur yang paling dekat dengan arah naik dan turun eskalator.

\subsection{LANTAI 3}
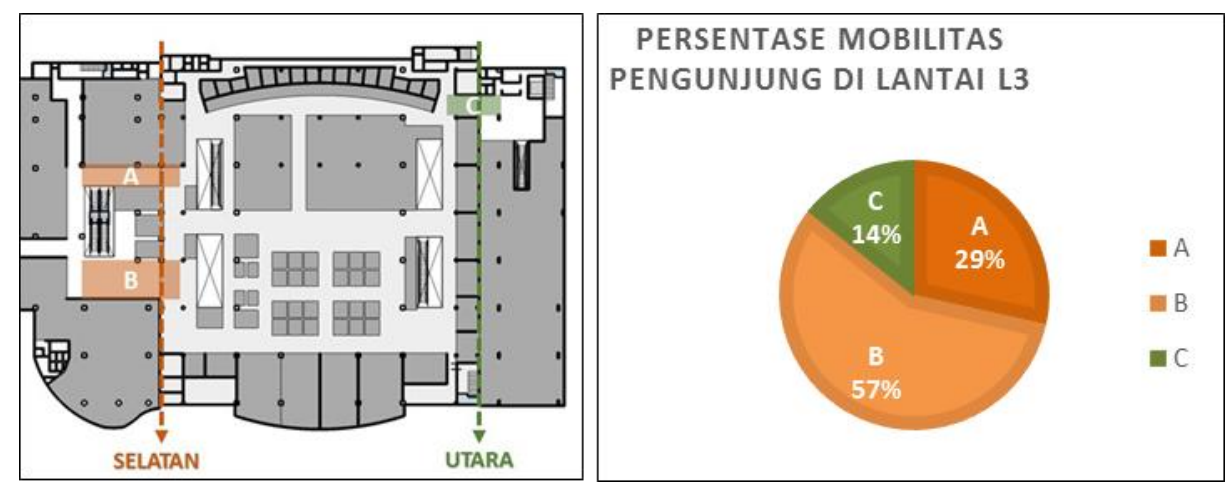

Figur 11. Posisi Jalur Pertemuan Pola (kiri) dan Persentase Jumlah Pengguna (kanan) di lantai L3.

Jumlah jalur pertemuan pada lantai 3 memiliki lalu lalang yang dianggap tinggi untuk pengunjung bergerak dari gedung lama dan baru, terutama dari sisi selatan lalu lalang pengunjung dapat dibilang tinggi, untuk persentase tertinggi diperoleh jalur $\mathrm{B}$ dengan $57 \%$, kebanyakan pengunjung melewati jalur ini untuk bisa mengakses eskalator ke lantai L3A, karena eskalator ini menjadi akses termudah menuju bioskop di L3A, lebar sirkulasi 6 meter, dilihat dari segi visual terlihat lapang dan lebar tanpa adanya pembatas baik dari jalur pertemuan $\mathrm{A}$ atau $\mathrm{B}$, dengan penerapan jalur seperti ini maka bagian jalur pertemuan menjadi terlihat paling mencuri perhatian, karena jalur gedung lama dan baru dibuat sebagai titik temu berupa node di tengah (Figur 7), hal ini membuat sirkulasi dapat terjadi secara leluasa, hal penarik lain karena di lantai 3 memiliki kekuatan daya tarik tersendiri sebagai area tujuan, karena memiliki tenant utama penarik seperti area entertainment dan makanan. Untuk sirkulasi di jalur $\mathrm{C}$ sewaktu-waktu dapat ramai dilalui pengunjung saat jam selesai ibadah gereja GBI yang berada pada sisi utara bangunan.

Table 2. Hasil Analisa Kondisi Jalur Pertemuan

\begin{tabular}{|c|c|c|c|c|c|c|}
\hline No & Lantai & Jalur & $\begin{array}{c}\text { Persen } \\
\text { ta-se }\end{array}$ & $\begin{array}{c}\text { Lebar } \\
\text { Bersih (M) }\end{array}$ & Standart & Faktor Penarik Jalur Sirkulasi \\
\hline 1 & SL & - & - & - & - & Pemanfaatan area parkir \\
\hline 2 & USL & - & - & - & - & Pemanfaatan area parkir \\
\hline \multirow{4}{*}{3} & \multirow{4}{*}{ LU } & A & $20 \%$ & 2,8 & $\begin{array}{c}\text { Tak } \\
\text { Memenuhi }\end{array}$ & \multirow{2}{*}{$\begin{array}{l}\text { Diapit oleh entrance pedestrian } \\
\text { utama bangunan. }\end{array}$} \\
\hline & & $\mathrm{B}$ & $47 \%$ & 3 & Memenuhi & \\
\hline & & $\mathrm{C}$ & $22 \%$ & 3.4 & Memenuhi & \multirow{2}{*}{ Keamanan jalur pejalan kaki. } \\
\hline & & $\mathrm{D}$ & $11 \%$ & 3 & Memenuhi & \\
\hline
\end{tabular}




\begin{tabular}{|c|c|c|c|c|c|c|}
\hline No & Lantai & Jalur & $\begin{array}{l}\text { Persen } \\
\text { ta-se }\end{array}$ & $\begin{array}{c}\text { Lebar } \\
\text { Bersih }(\mathbf{M})\end{array}$ & Standart & Faktor Penarik Jalur Sirkulasi \\
\hline \multirow{4}{*}{4} & \multirow{4}{*}{ LG } & A & $21 \%$ & 2,8 & $\begin{array}{c}\text { Tak } \\
\text { Memenuhi }\end{array}$ & \multirow{2}{*}{$\begin{array}{l}\text { Keberadaan inline tenant. } \\
\text { Sejajar dengan jalur hierarki utama } \\
\text { BEC1. } \\
\text { Dekat dengan entrance utama. } \\
\end{array}$} \\
\hline & & B & $54 \%$ & 3,4 & Memenuhi & \\
\hline & & $\mathrm{C}$ & $7 \%$ & 3,4 & Memenuhi & \multirow{2}{*}{$\begin{array}{l}\text { Dekat dengan entrance utama. } \\
\text { Berhadapan langsung dengan pintu } \\
\text { lift. }\end{array}$} \\
\hline & & $\mathrm{D}$ & $18 \%$ & 2,8 & $\begin{array}{c}\text { Tak } \\
\text { Memenuhi }\end{array}$ & \\
\hline \multirow{4}{*}{5} & \multirow{4}{*}{ UG } & A & $26 \%$ & 2,8 & $\begin{array}{c}\text { Tak } \\
\text { Memenuhi }\end{array}$ & \multirow{2}{*}{$\begin{array}{l}\text { Pandangan visual telihat jelas } \\
\text { Sejajar dengan jalur hierarki utama } \\
\text { BEC } 1 .\end{array}$} \\
\hline & & $\mathrm{B}$ & $52 \%$ & 7,2 & Memenuhi & \\
\hline & & $\mathrm{C}$ & $12 \%$ & 3,4 & Memenuhi & \multirow{2}{*}{ Sejajar dengan lobby lift } \\
\hline & & $\mathrm{D}$ & $10 \%$ & 3,7 & Memenuhi & \\
\hline \multirow{4}{*}{6} & \multirow{4}{*}{ L1 } & A & $26 \%$ & 2,8 & $\begin{array}{c}\text { Tak } \\
\text { Memenuhi }\end{array}$ & \multirow{2}{*}{$\begin{array}{l}\text { Keberadaan inline tenant. } \\
\text { Sejajar dengan jalur hierarki utama } \\
\text { BEC1. }\end{array}$} \\
\hline & & $\mathrm{B}$ & $52 \%$ & 4 & Memenuhi & \\
\hline & & $\mathrm{C}$ & $11 \%$ & 3,4 & Memenuhi & \multirow{2}{*}{ - } \\
\hline & & $\mathrm{D}$ & $11 \%$ & 7,5 & Memenuhi & \\
\hline \multirow{5}{*}{7} & \multirow{5}{*}{$\mathrm{L} 2$} & A & $34 \%$ & 2,8 & $\begin{array}{c}\text { Tak } \\
\text { Memenuhi }\end{array}$ & \multirow{2}{*}{$\begin{array}{l}\text { Dekat dengan akses eskalator naik } \\
\text { dan turun. }\end{array}$} \\
\hline & & B & $48 \%$ & 3,7 & Memenuhi & \\
\hline & & $\mathrm{C}$ & $7 \%$ & 3,4 & Memenuhi & \multirow{3}{*}{$\begin{array}{l}\text { Dekat dengan akses eskalator naik } \\
\text { dan turun. } \\
\text { Sejajar dengan akses menuju } \\
\text { eskalator. }\end{array}$} \\
\hline & & $\mathrm{D}$ & $8 \%$ & 3,7 & Memenuhi & \\
\hline & & $\mathrm{E}$ & $3 \%$ & 3,7 & Memenuhi & \\
\hline \multirow{3}{*}{8} & \multirow{3}{*}{ L3 } & $\mathrm{A}$ & $29 \%$ & 3,2 & Memenuhi & \multirow{2}{*}{$\begin{array}{l}\text { Dekat dengan akses eskalator naik } \\
\text { dan turun menuju L3A. }\end{array}$} \\
\hline & & $\mathrm{B}$ & $57 \%$ & 6 & Memenuhi & \\
\hline & & $\mathrm{C}$ & $14 \%$ & 3,4 & Memenuhi & - \\
\hline 9 & L3A & - & - & & - & Tidak Ada \\
\hline \multicolumn{3}{|c|}{ Keterangan } & $\begin{array}{l}\text { Jalur Bat } \\
\text { Jalur Bat } \\
\text { Persentas } \\
\text { Persentas }\end{array}$ & $\begin{array}{l}\text { Selatan } \\
\text { Utara } \\
\text { Tertinggi Pad } \\
\text { Tertinggi Pad }\end{array}$ & $\begin{array}{l}\text { atas Selatan } \\
\text { atas Utara }\end{array}$ & \\
\hline
\end{tabular}

Kesimpulan didapatkan, dimensi lebar suatu jalur sirkulasi tidak mengahalangi pengunjung untuk melakukan mobilitas ke tempat tujuan, dikarenakan pada jalur yang lebarnya tak memenuhi standart memiliki persentase mobilitas yang cukup tinggi mencapai 34\% pengunjung di dalam satu lantai. Namun untuk dimensi lebar jalur akan lebih nyaman bila memenuhi standart minimal sirkulasi perbelanjaan dan lebar disesuaikan dengan jumlah lalu lalang pengunjung. Maka jalur sirkulasi guna memudahkan mobilitas pengunjung di dalam bangunan perbelanjaan BEC dianggap tak efektif dikarenakan terdapat jalur-jalur yang tak memenuhi standart minimal sirkulasiyang memberikan efek terjadi kepadatan pada jalur sirkulasi yang menghambat mobilitas pengunjung.

\section{KEMUDAHAN MOBILITAS PENGUNJUNG}

Tipe desain BEC memiliki tipe desain bertingkat banyak/ multi-level design, sehingga untuk melihat keefektivan penggabungan pola sirkulasi pengunjung yang ada antara BEC lama dan BEC baru pengunjungnya tidak hanya dilihat dari 1 lantai saja namun hubungan antar tiap lantai satu sama lainnya. Dari teori yang telah didapatkan faktor yang dapat meningkatkan dan memperluas aliran sirkulasi/ flow activity pengunjung dapat dilakukan dengan pertimbangan 
perletakan entrance, jalur sirkulasi antar koridor, media sirkuasi vertikal, dan perletakan tenant. Oleh karena itu akan dilakukan analisa ketiga aspek tersebut dikaitkan dengan pola sikulasi BEC secara keseluruhan antar lantai.

Untuk pemilihan media sirkulasi vertikal, ditetapkan pada penggunaan eskalator. Eskalator pada sebuah bangunan perbelanjaan dianggap sebagai media sirkulasi vertikal yang paling efektif, hal ini dikarenakan eskalator mampu mengangkut pengguna secara terus menerus. Untuk bangunan perbelanjaan, menurut standar Architects' Data Third Edition 7, data persentase penggunaan sirkulasi vertikal adalah, tangga $2 \%$, lift $8 \%$, dan eskalator $90 \%$. Bila dihitung perbandingannya BEC menggunakan jumlah lift menerus dari lantai SL-L3A sebanyak 5 buah saja, dan eskalator sebanyak 65 buah yang tersinambung dari lantai SL-L3A, dan tangga hanya digunakan untuk tangga kebakaran, maka untuk persentase media sirkulasi vertikal BEC didominasi oleh eskalator sebesar 93\%. Proses mobilitas pengunjung diawali dari 15 titik entrance yang ada di lantai SL, USL, LU, LG, dan UG .menuju ke tenant tujuan, atau media sirkulasi vertikal eskalator yang sesuai dengan kemudahan jalur.

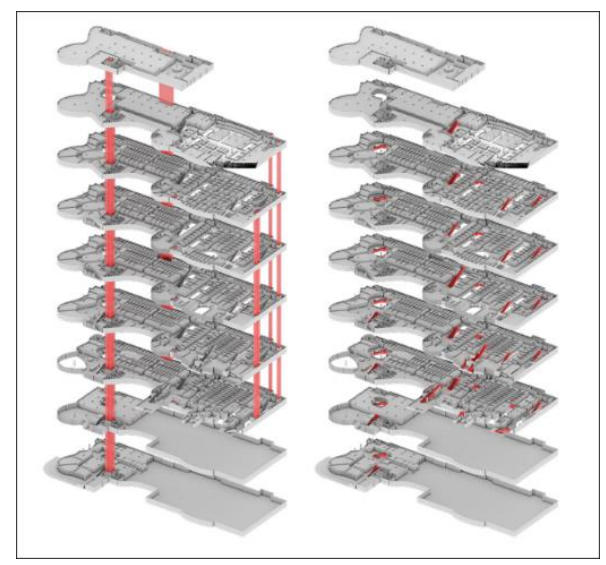

Figur 12. Penempatan Media Sirkulasi Vertikal Lift (Kiri), dan Eskalator (Kanan).

\subsection{STREET LEVEL \& UPPER STREET LEVEL}
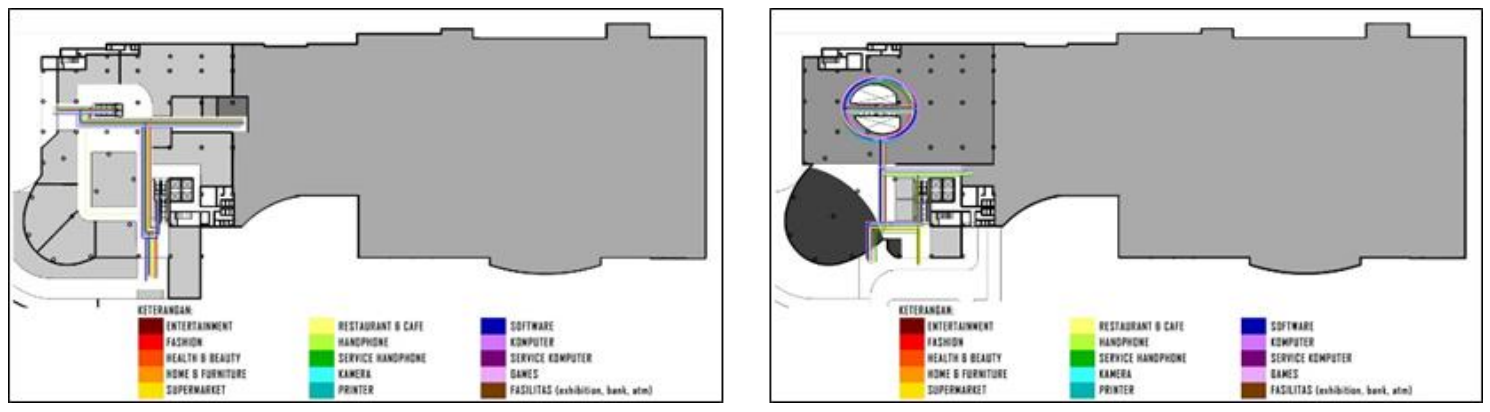

Figur 13. Mobilitas Pengunjung Lantai USL (Kiri) \& LU (Kanan) Berdasarkan Tenant Tujuan.

Pada Lantai SL dan USL merupakan lantai tambahan yang hanya ada pada area bangunan baru, memiliki 2 entrance drop off, pada gambar diatas terlihat pada pengguna eskalator lokasi 7 (Figur 12) jalur sirkulasi dilakukan dengan menembus ruang, karena secara terpaksa pangunjung yang ingin naik dari lantai SL ke USL harus melewati tenant Lotte Mart terlebih dahulu. 


\subsection{LOWER UPPER}

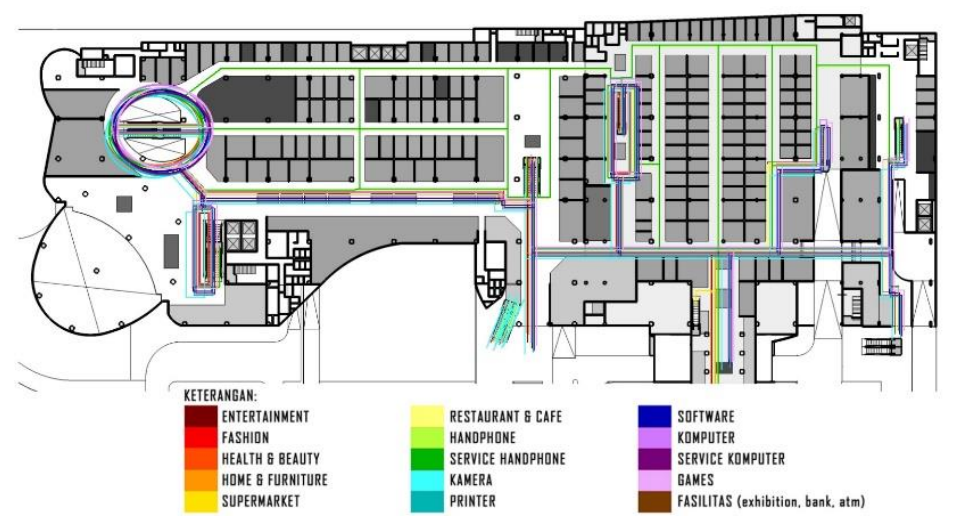

Figur 14. Mobilitas Pengunjung Lantai LU Berdasarkan Tenant Tujuan.

Pada lantai ini terdapat 4 titik jalur pertemuan, pada lantai ini jalur pertemuan tertinggi pada titik B sebesar 47\%, untuk memperjelas data yang sudah didapat maka akan dianalisa dari ilustrasi tujuan pengunjung yang sudah dibuat dengan data dari lampiran 2. Dari perhitungan grafik dan data yang sudah didapat, maka didapatkan perbandingann data persentase mobilitas pengunjung dan persentase pembagian jenis tenant tujuan yang pengunjung lalui sebagai berikut. Didapatkan dari perbandingan jalur B memiliki persentase tertinggi, dengan perbandingan data $47 \%$ dan kebutuhan ke arah tenant tujuan $43 \%$

\subsection{LOWER GROUND}

Pada lantai ini terdapat 4 titik jalur pertemuan, pada lantai ini jalur pertemuan tertinggi pada titik B sebesar 52\%. Dari perhitungan grafik dan data yang sudah didapat, maka didapatkan perbandingann data persentase mobilitas pengunjung dan persentase pembagian jenis tenant tujuan yang pengunjung lalui sebagai berikut. Didapatkan dari perbandingan jalur B memiliki persentase tertinggi, dengan perbandingan data 52\% dan kebutuhan ke arah tenant tujuan $44 \%$

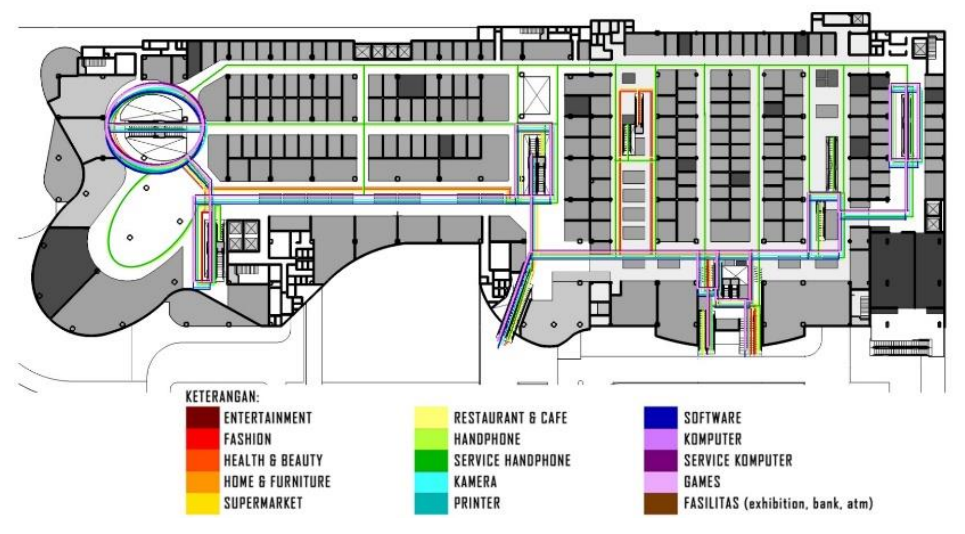

Figur 15. Mobilitas Pengunjung Lantai LG Berdasarkan Tenant Tujuan.

\subsection{UPPER GROUND}

Pada lantai ini terdapat 4 titik jalur pertemuan, pada lantai ini jalur pertemuan tertinggi pada titik B sebesar 52\%. Dari perhitungan grafik dan data yang sudah didapat, maka didapatkan perbandingann data persentase mobilitas pengunjung dan persentase pembagian jenis tenant tujuan yang pengunjung lalui sebagai berikut. Didapatkan dari perbandingan jalur 
B memiliki persentase tertinggi, dengan perbandingan data 52\% dan kebutuhan ke arah tenant tujuan $44 \%$

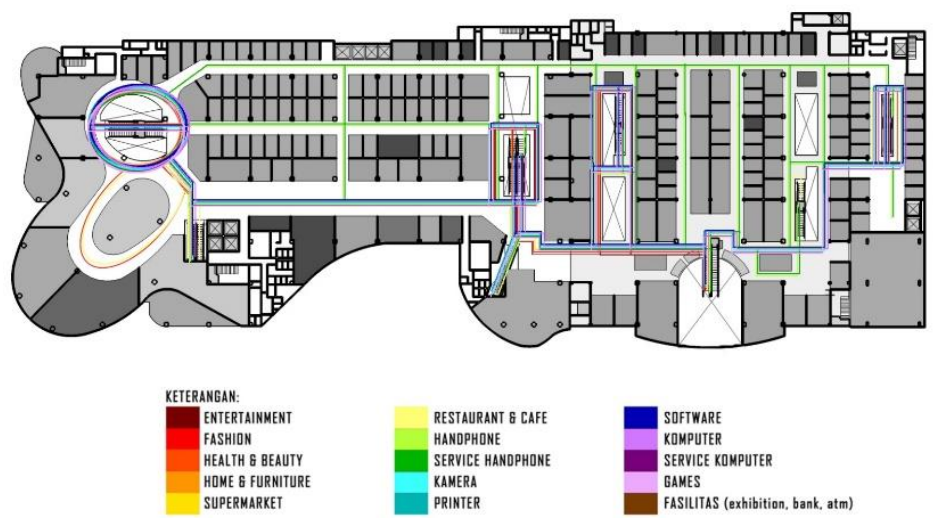

Figur 16. Mobilitas Pengunjung Lantai UG Berdasarkan Tenant Tujuan.

\subsection{LANTAI 1}

Pada lantai ini terdapat 4 titik jalur pertemuan, pada lantai ini jalur pertemuan tertinggi pada titik B sebesar 52\%. Dari perhitungan grafik dan data yang sudah didapat, maka didapatkan perbandingann data persentase mobilitas pengunjung dan persentase pembagian jenis tenant tujuan yang pengunjung lalui sebagai berikut. Didapatkan dari perbandingan jalur B memiliki persentase tertinggi, dengan perbandingan data 52\% dan kebutuhan ke arah tenant tujuan $39 \%$

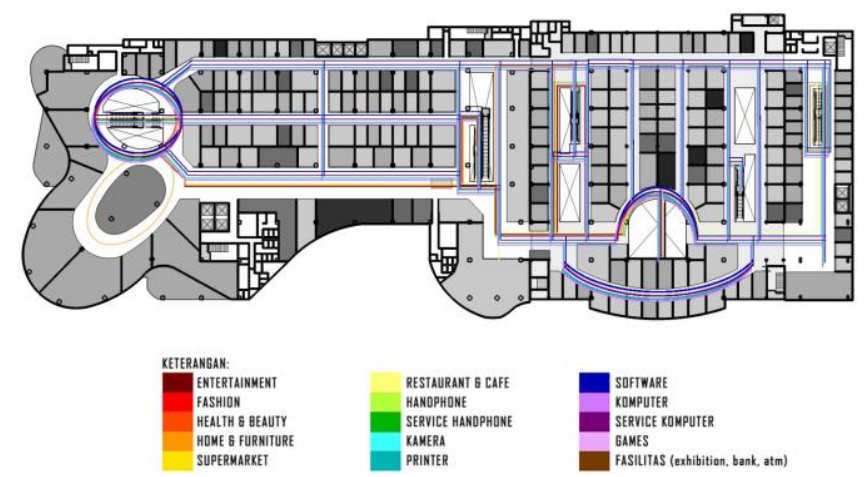

Figur 17. Mobilitas Pengunjung Lantai 1 Berdasarkan Tenant Tujuan.

\subsection{LANTAI 2}

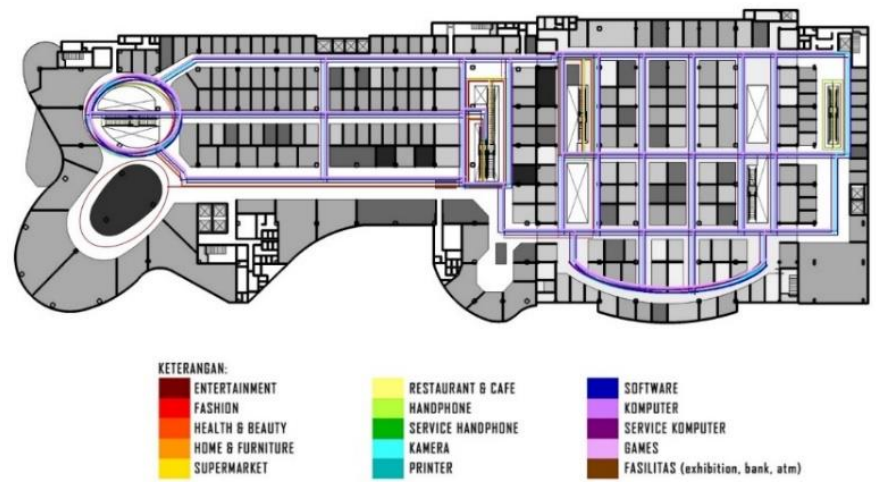

Figur 18. Mobilitas Pengunjung Lantai 2 Berdasarkan Tenant Tujuan. 
Pada lantai ini terdapat 5 titik jalur pertemuan, pada lantai ini jalur pertemuan tertinggi pada titik B sebesar. Didapatkan dari perbandingan jalur B memiliki persentase tertinggi, dengan perbandingan data $48 \%$ dan kebutuhan ke arah tenant tujuan $27 \%$. Untuk persentase menurut tenant lebih merata, namun untuk data yang ada terjadi perbandingan yang cukup besar dari yang tertinggi $48 \%$ dan terendah 3\%, hal ini dimungkinkan ada faktor lain yang mempengaruhi mobilitas pengunjung, baik dari segi visual maupun unsur sirkulasi.

\subsection{LANTAI 3}

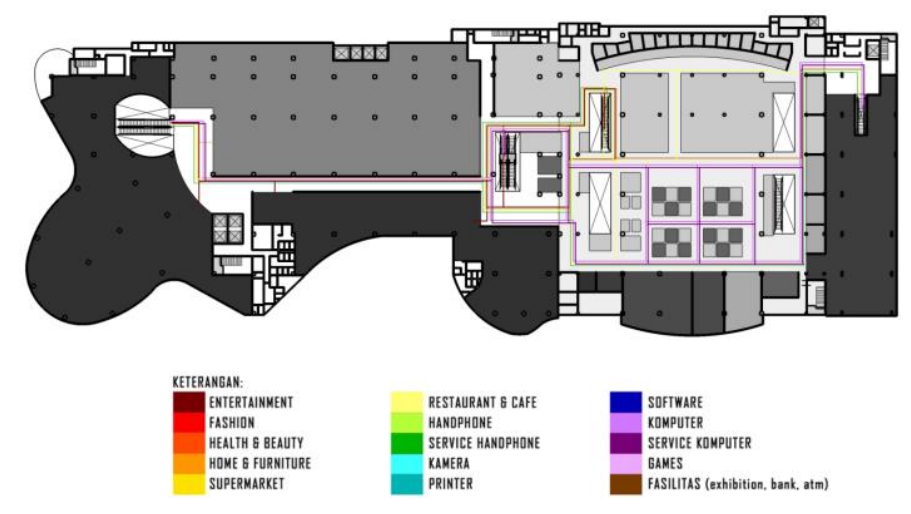

Figur 19. Mobilitas Pengunjung Lantai L3 Berdasarkan Tenant Tujuan.

Pada lantai ini terdapat 3 titik jalur pertemuan, pada lantai ini jalur pertemuan tertinggi pada titik B sebesar 57\%. Dari perhitungan grafik dan data yang sudah didapat, maka didapatkan perbandingann data persentase mobilitas pengunjung dan persentase pembagian jenis tenant tujuan yang pengunjung lalui sebagai berikut. Didapatkan dari perbandingan jalur B memiliki persentase tertinggi, dengan perbandingan data 57\% dan kebutuhan ke arah tenant tujuan $44 \%$.

\subsection{LANTAI 3 A}
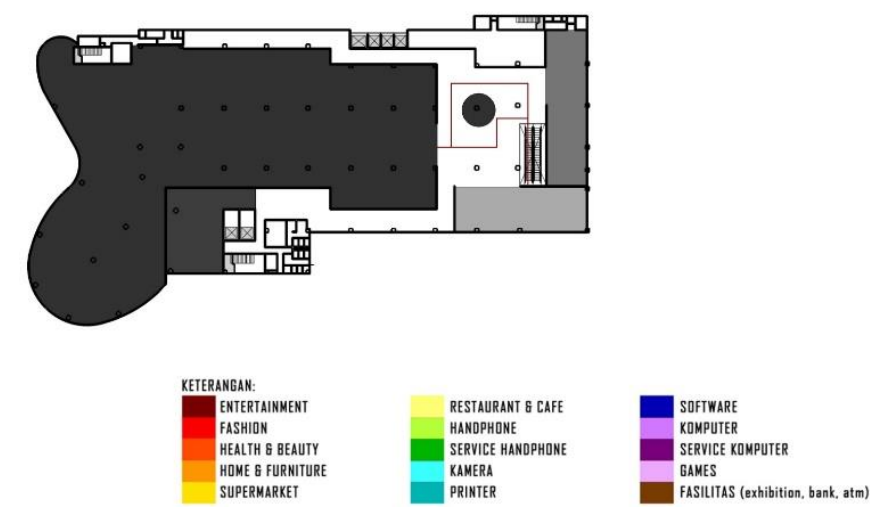

Figur 20. Mobilitas Pengunjung Lantai 3A Berdasarkan Tenant Tujuan.

Untuk lantai L3A, terdapat fungsi tenant terbesar yang mampu menarik pengunjung untuk berjalan ke lantai bangunan teratas, hal ini penempatan bioskop atau anchor pada lantai L3A berhasil untuk diterapkan di dalam bangunan perbelanjaan.

Jalur mobilitas pengunjung dipengaruhi oleh pola sirkulasi dalam suatu bangunan. Pola sirkulasi terbentuk dari adanya unsur-unsur sirkulasi yang mendukung proses mobilitas pengunjung. Dari analisa di atas, didapatkan persentase tertinggi data mobilitas pengunjung pada jalur sirkulasi, sebanding dengan analisa pola sirkulasi yang terbentuk dari kebutuhan 
pengunjung menuju tenant tertentu secara efektif. Hasil analisa jalur sirkulasi dan kemudahan mobilitas pengunjung dirangkum dalam tabel sebagai berikut:

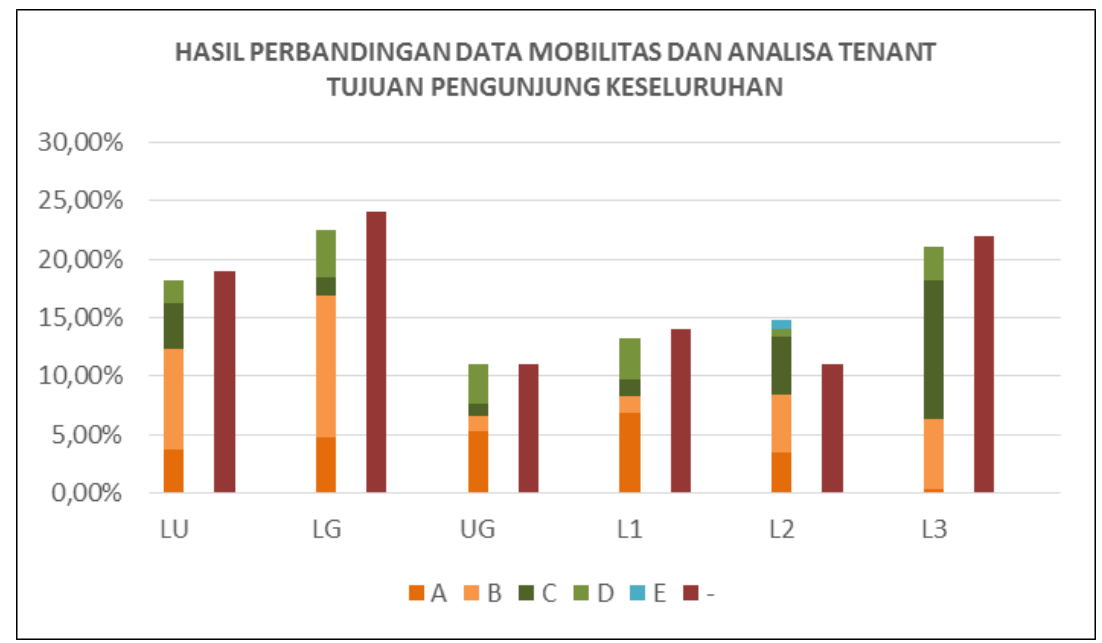

Figur 21. Diagram Hasil Perbandingan Data Mobilitas dan Analisa Tenant Tujuan Pengunjung Keseluruhan.

Dilihat dari Tabel 3 yang kemudian diperjelas dengan keberadaan grafik pada Figur 21 dominansi persentase mobilitas pengunjung terlihat pada lantai LG dan lantai UG, dengan dominansi keseluruhan pada titik jalur B. Ketimpangan persentase ini menghasilkan kesimpulan pola sirkulasi pada bangunan BEC, penggabungan loop plan dan linear plan pada bangunan ini tidak efektif, dikarenakan mobilitas pengujung tak merata pada jalur-jalur pertemuan antara gedung lama dan gedung baru, dengan persentase mobilitas yang terlihat timpang dari jumlah pengguna yang lebih condong pada satu zona tertentu.

\section{EFEKTIVITAS POLA SIRKULASI DENGAN KEMUDAHAN MOBILITAS PENGUNJUNG}

Untuk hasil kesimpulan secara keseluruhan maka bangunan BEC dianggap sinambung antara bangunan lama dan bangunan baru karena mobilitas tetap terjadi satu sama lain, namun untuk efektifitas jalur sirkulasi dan penerapan pola dianggap tidak efektif.

Pada hasil kesimpulan data Figur 21 dominansi mobilitas lebih dari $20 \%$ terletak apda lantai LG dan L3, maka dapat ditemukan bahwa 2 lantai tersebut memiliki pola sirkulasi yang mengarahkan mobilitas pengunjung paling tinggi. Maka akan dilihat penerapan pola yang dianggap efektif pada bangunan BEC dilihat dari lantai LG dan L3.

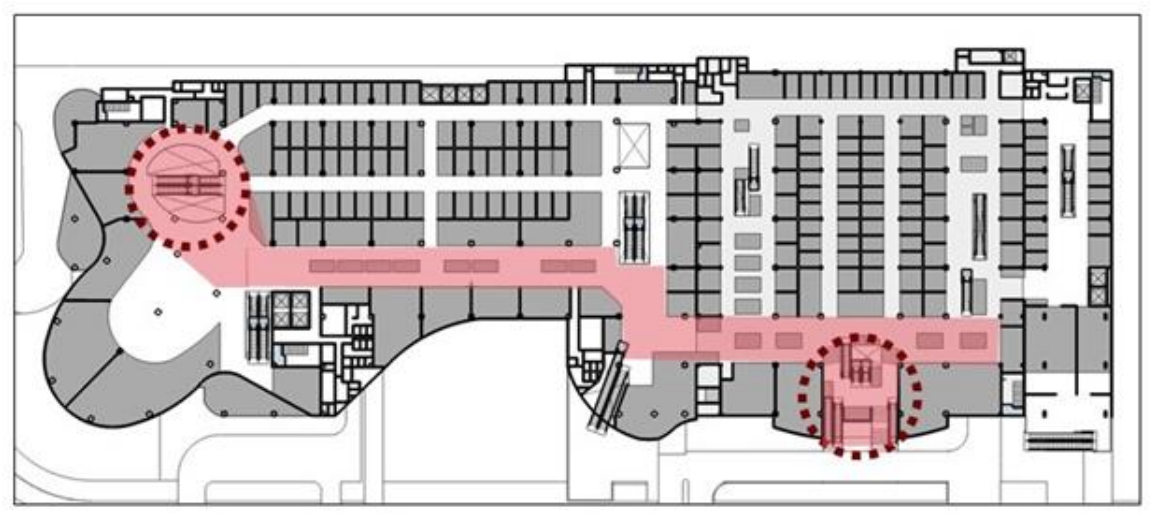

Figur 22. Hubungan Sirkulasi Utama BEC Baru dan BEC Lama Lantai LG 
Pada lantai LG Pengunjung akan lebih mudah membaca koridor pada hierarki yang terlebar, dikarenakan hierarki sirkulasi pada bangunan BEC lama dan baru tetap dipertahankan dan diarahkan meskipun tak terjadi secara sejajar.

Pada analisa node terkuat dan koridor terkuat lantai LG, terjadi pola sirkulasi yang terbentuk dari 2 titik node yang menguatkan yaitu pada entrance utama bangunan lama dan titik entrance bangunan baru yang diarahkan menggunakan media sirkulasi vertikal, pada bagian koridor utama memang memiliki kelebaran yang sama namun terputus pada bagian tengahnya dan tidak sejajar antar koridor BEC lama dan Koridor BEC baru (Figur 22).

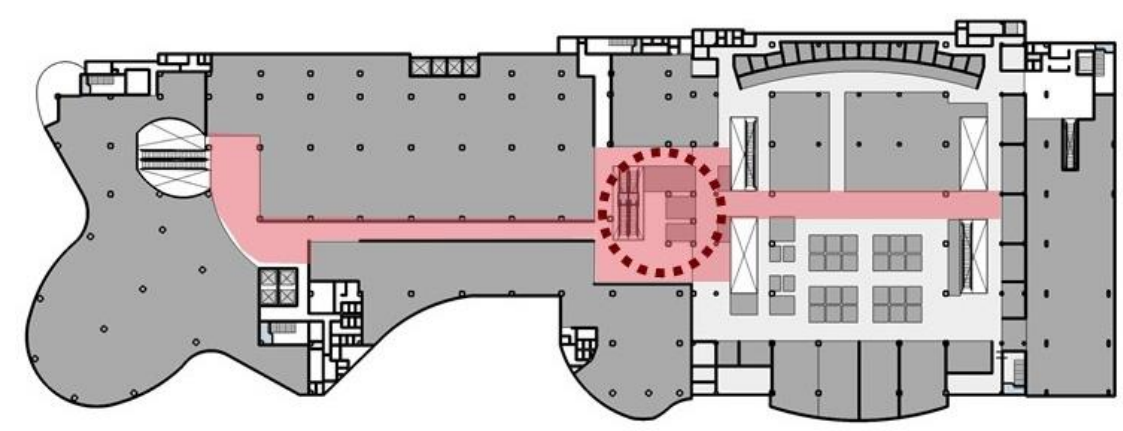

Figur 23. Hubungan Sirkulasi Utama BEC Baru dan BEC Lama Lantai L3

Lantai 3 pada bangunan BEC, memiliki koneksi pola sirkulasi antar node dan koridor yang berbeda dari lantai sebelumnya. Node terkuat diletakan tepat di tengah, yaitu pada jalur pertemuan pola sirkulasi gedung lama dan gedung baru. Diperkuat dengan hierarki koridor secara linear pada bagian tengahnya yang mengarahkan dari utara-selatan dan sebaliknya (Figur 23).

\section{PENUTUP}

Kejelasan pola sirkulasi mempengaruhi kemudahan pengunjung dalam melakukan pergerakan/ mobilitas, khususnya dalam mempermudah untuk mencapai ke tempat tujuan. Beberapa contoh yang ditemukan dan berhasil untuk digunakan adalah pola yang digunakan harus memiliki perkuatan hierarki antara koridor yang kemudian diperkuat lagi dengan pengadaan node. Sesuai dengan prinsip penggunaan pola sirkulasi, loop plan memiliki kesamaan pola dengan node, dan linear plan memiliki kesamaan pola dengan koridor. Dari hal tersebut dapat ditemukan pola-pola yang menunjang satu sama lain, seperti ilustrasi gambar di bawah.

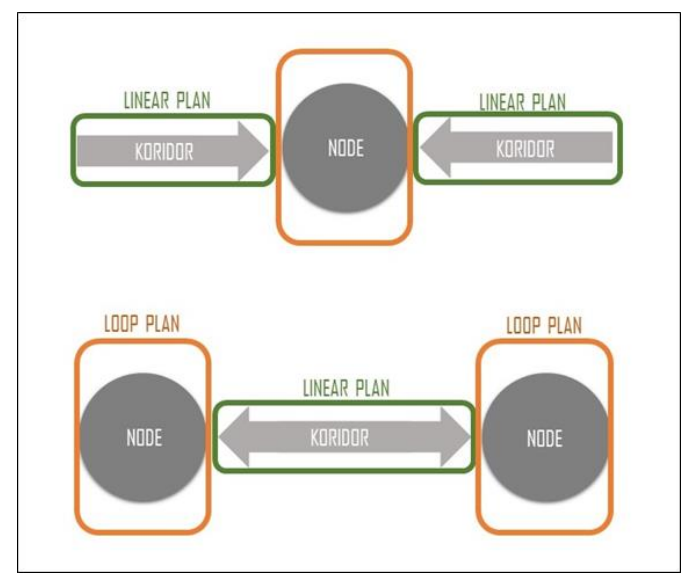

Figur 24. Ilustrasi Penerapan Pola Sirkulasi dengan Loop Plan dan Linear Plan 
Oleh karena itu penggunanan linear plan dan loop plan dapat saling berkesinambungan secara seimbang bila terdapat pola yang melengkapi satu sama lain. Dengan sifat loop plan yang terpusat dan sifat linear plan yang mengarahkan, maka loop plan dan linear plan dapat digabungkan dengan arahan jalur yang jelas. (Figur 24)

Dalam membuat suatu pusat perbelanjaan gedung baru, agar dapat sinambung dengan bangunan di gedung lama, perlu diperhatikan jalur-jalur pertemuan yang berpotensi agar pengunjung dapat dengan mudah berpindah secara merata antar bangunan gedung lama dan gedung baru. Jalur temuan punya efektivitas yang tinggi bila memiliki visualisasi yang terbuka ke jalur sirkulasi utama gedung lama, node dan koridor harus sejajar dengan kondisi node dan koridor gedung lama, dimana jalur-jalur pertemuan ini dijadikan sebagai penghubung sirkulasinya. Jalur sirkulasi dapat dengan mudah menarik pengunjung bila terdapat anchor ${ }^{8}$ utama diantaranya sebagai penarik, arah jalur perpindahan media sirkulasi vertikal diarahkan secara seimbang, dan pengadaan inline tenant pendukung dapat membantu meningkatkan mobilitas pengunjung.

\section{DAFTAR PUSTAKA}

Beddington, N. (1982). Design for Shopping Centres. London: Butterworths Design Series

Leung, D. D. (2009). First Steps Toward a Shopping Center Typology for Southeast Asia, Asia-Pacific and Beyond. ICSC's Asia Research Council.

Darlow, C. (1972). Enclosed Shopping Centres. the University of California: Architectural Press.

Lawrence J, I. (1994). Store Palnning/Design: History, Theory, Process. Wiley.

Visser, H. , Shopping centres: investigating the need for a regional shopping centre. Disertasi tidak diterbitkan, 2010, North-West University

Northen, R. I. (1977). Shopping Centres: A Developer's Guide to Planning and Design. College of Estate Management.

Ching, Francis D.K. (2007). Architecture: Form, Space \& Order, 3rd ed. John Wiley. Hoboken.

Reurbanist. (2017, Maret 7). Circulation System. Diambil kembali dari http://reurbanist.com/2011/03/circulation-system/ 